\title{
Interfaces
}

INTERFACES Image Texte Language

$41 \mid 2019$

Images / Memories

\section{Pablo Maurette, The Forgotten Sense. Meditations on} Touch

\section{Christine Sukic}

\section{Q OpenEdition \\ 1 Journals}

\section{Electronic version}

URL: http://journals.openedition.org/interfaces/652

DOI: $10.4000 /$ interfaces.652

ISSN: 2647-6754

Publisher:

Université de Bourgogne, Université de Paris, College of the Holy Cross

\section{Printed version}

Date of publication: 21 June 2019

Number of pages: 139-140

ISSN: 1164-6225

\section{Electronic reference}

Christine Sukic, "Pablo Maurette, The Forgotten Sense. Meditations on Touch", Interfaces [Online], 41 ।

2019, Online since 21 June 2019, connection on 07 January 2021. URL: http://

journals.openedition.org/interfaces/652; DOI: https://doi.org/10.4000/interfaces.652

Les contenus de la revue Interfaces sont mis à disposition selon les termes de la Licence Creative Commons Attribution 4.0 International. 


\title{
MAURETTE, PABLO, THE FORGOTTEN SENSE. MEDITATIONS ON TOUCH, CHICAGO AND LONDON, THE UNIVERSITY OF CHICAGO PRESS, 173 PP.
}

\author{
Christine Sukic \\ Université de Reims Champagne-Ardenne
}

Pablo Maurette's book is more than an academic work. Originally published in Spanish in 2015, this collection of six essays is presented by its author in the preface as a meditation on textual material and the sense of touch. It is that, along with many other things. For the reader, it could be envisaged as an experience, not only a reading experience but also a tactile one, since the cover of the book is made of soft material, which enhances the experience of reading by the particular feel of one's fingers holding it. But after all, as Maurette himself suggests, author and reader are linked anyway through the sense of touch, since both acts of writing and reading are accomplished with the help of our hands. So when the author writes, whether it is with a pen or a laptop, and the reader reads, from a book-one hopes - but even from any other medium, the hands are involved. Touching the reader should therefore be understood both in the figurative and in the literal sense.

In the wake of numerous studies on the senses, and the development of sensory studies, Maurette's work purports to rehabilitate the "forgotten" sense of touch, an epithet that he immediately questions, but that can be understood in the long history of ocularcentrism (the domination of the sense of sight) from Plato and Aristotle down to the Renaissance Neoplatonists. However, as Maurette rightly explains, the sense of touch is central in that it is involved with other senses and ultimately governs affects, even though it is, these days, threatened by virtual reality.

In order to appreciate this book, one has to agree to be taken by the hand and be led on what first looks like a labyrinthine journey through numerous philosophical, literary or visual works. Maurette can start with a reflexion on Aristotle, which leads him to Lucretius - On the Nature of Things is central to his reflection and he often reaches back to it - then to Moby Dick before opening his copy of the Iliad. He works as a comparatist, which is why he does not hesitate to associate different time periods, genres or geographical areas, but most of all, the book also follows his own experience as a reader. Often using the first person, he also accompanies us through the shelves of different libraries - the Bodleian or the Bibliothèque Nationale de France - seizing books that are in open access as he is waiting for the ones he has ordered and flipping through the pages of different works, which 
could account for his propensity to favour associations of ideas, but it is also curiosity, experience and mainly his knowledge, including philological, that provides for the sense of profusion.

Not that this book is a random assemblage of references. Maurette's main interest is the text, the texture of the text to be more precise, so that anybody who has a feel for poetry-in the broader sense of the word as literature-will be touched. This common thread is aptly summed up by the idea of the haptic, a word first used by art historian Alois Riegl at the beginning of the twentieth century and that Maurette re-introduces throughout his book, making it the seat of a synaesthetic relationship between touch and sight, through which we are able to anticipate the texture of things without having to touch them.

In fact, Maurette seems to be tackling the — scholarly or not-reader's special relation with the literary text, one that is at once distant, purely intellectual, and based on emotion and affect. A text is first and foremost a book, an object that is held and touched, such as when Maurette describes handling the editio princeps of Lucretius's On the Nature of Things (first published in Italy in 1473). A book is not just made up of ideas and words, but is touched and touching in many ways. So when Maurette embarks on one of his philological analyses - looking for example at the verb contingo used by Lucretius to describes the smearing of the rim of a glass containing bitter medicine - he is obviously searching for the texture or the touch of the text (or the book, we might say), that moment when one is at once intellectually excited by a literary work, but also emotionally touched. This is also particularly obvious when Maurette evokes the craftsmanship involving dactylic poetry in Homer's epics, or a little-known Renaissance dialogue on kissing, Delfino or, on the Kiss (c.1577) by Dalmatian-born Francesco Patrizi that describes all the possibilities of an encounter between two mouths.

Unsurprisingly, this book is enjoyable both as an intellectual journey through the text of various works, and as a tactile account of the experience and close relation to the text of a practitioner of literature. The pleasure is enhanced by Maurette's impeccable style and his capacity to tell stories, of books, works of art, or words. 